\title{
Expanded Education in Rescue in Physiotherapy and Nursing in V4 - Adaptation for Refugee Crisis (Letter)
}

\author{
M. Sramkova (Maria Sramkova)',2, J. Otrubova (Jana Otrubova)', V. Kozon (Vlastimil \\ Kozon)', P. Vansac (PeterVansac) 1,5, P. Czarnecki (Pawel Czarnecki) ${ }^{1,4}$, J. Benca (Juraj \\ Benca)', J. Ridosko (Jaroslav Ridosko)', L. Matulnikova (Ludmila Matulnikova)', \\ G. Herdics (Görgy Herdics)', J. Vallova (Jana Vallova)', M. Bednarikova (Miroslava \\ Bednarikova)', M. Palun (Miroslav Palun)', C. Muss (Claus Muss) ${ }^{1,3}$
}

${ }^{1}$ St. Lesley College of SEU, Nove Zamky, SK

Original Article

2 St. John Neumann Institute, Pribram, CZ

${ }^{3}$ IGAP, Zurich, $\mathrm{CH}$

${ }^{4}$ SEUC Program for Refugees and Migrants, Vámoszabadi, HU

${ }^{5}$ Management University, Warsaw, PL

${ }^{6}$ University Hospital Trencin, SK

\section{E-mail address:}

mariasramkova@zoznam.sk

\section{Reprint address:}

Maria Sramkova

St Lesley College Branch Parizanske

Partizanske, SK

Source: Clinical Social Work and Health Intervention

Pages: $76-78$

Volume: 9

Issue: 3

Cited references: 4

\section{Reviewers:}

Peter G. Fedor-Freybergh - editor@nel.edu

\section{Key words:}

Physiotherapy, Nursing.

\section{Publisher:}

International Society of Applied Preventive Medicine i-gap

CSWHI 2018; 9(3): 76 - 78; DOI 10.22359/Cswhi_9_3_12 @ 2018 Clinical Social Work and Health Intervention

\section{Abstract:}

Current letter to the editor reflects on a series of papers published in Clinical Social Work Journal (1-3) on refugee's and migrant's health care during the new 2015-2018 crisis. The unpreparedness of most 
non-doctor Health Care Workers solve health and social problems migrants and refugees have due to the lack of language and education in migrant/refugee health and related topics. The majority of V4 + Austria countries deal with, but very few teach socio-legal problems of children and mothers; reunifications of families; humanitarian deals; tropical diseases; other subjects which appeared from the praxis during these four years of migrant crisis in Greece/Italy, where 1.5million per year of immigrants and refugees escaped via Balkan or Mediterranean Route and are potential V4 citizens.

Several papers have been published concerning the new roles of Health Care Workers in the Migrant and Refugee crisis, including in the Clinical Social Work and Health Intervention (1-3). As seen in those papers, the role of other-than-doctor (OTD) Health Care Workers (HCW) is a part of the work of essential Physicians and Nurses among arrived migrants. Refugees, Physiotherapists in rehabilitation of post war victims; midwifery in deliveries of migrant mothers in the field; rescuers in acute cases of those escaping their houses and traveling via the Mediterranean Route with the risk of life-threatening events on the sea (drowning) and crossing borders (asthma, diabetes).

Table 1 shows all the new challenges they have to face (HCW OTD-HCW) due the new situation after 2015 refugee crisis.

\section{References}

1. MOLNAROVA K, ONDOVA P, ZOLLER K, ADAMCOVA A et al (2017) Low Number of Neuroinfections in Migrants to Greece from Syria and Iraq Comparison to Migrants from Burundi and Congo to Rwanda. Clinical Social Work and Health Intervention Vol. 8 No. 22017

2. BELOVICOVA M, LISKOVA A, HRINDOVA T et al (2017) Low Prevalence of MRSA in Physiotherapy and Gym Facilities in a Greek Refugee Camp. Clinical Social Work and Health Intervention Vol. 8 No. 22017.

3. KHALED I, ALI HAJ P, KRCMERY V, KALATOVA D, GALLOVA A, BAK T, SCHUMMAN I, DUDOVA Z, ZOLLER K, REITH B, OBTULOVIC M, OLAH M, HRINDOVA T, BELOVICOVA M (2017)

Table 1: New events in Health Care with OTD-HCW, challenges after the 2015 Refugee crisis

\section{Profession}

Podiatrists

Physiotherapy

Midwifery

Rescuers

Dental assistants

Medical technology

Public Health

Nutritionist

Social worker

\section{New events to be solved}

Wound therapy, assisting in field surgeries

Wound therapy, amputation assistance

Field births of pregnant women

Diabetic coma, asthmatic status, myocardial infarction, strokes, allergic \& anaphylactic reactions

Complete dental care if no dentist available

Field lab, point of care tests, RDTs

Community Health, water \& sanitation interventions, epidemics prevention

Anti-malnutrition Program for children \& mothers

Social protection of children, unification of families 
Spectrum of infections in physiotherapy and rehabilitation ward for war victims and veterans from Iraq and Syria (short note). Clinical Social Work and Health Intervention. 8. 26-28. 10.22359/cswhi_8_2_05.
4. ALI HAJ P et al (2016) Are migrants from Middle East carriers of multi-resistant bacteria? Clinical Social Work and Health Intervention Vol. 7 No. 320162. 